This is a post-peer-review, pre-copyedit version of an article published in URBAN DESIGN International. The definitive publisher-authenticated version Istrate, Aura-Luciana, Chen, Fei, Kadetz, Paul, Chang, Ying and Williams, Austin Rhys (2021) Developing an analytical framework for liveable streets in Shanghai. URBAN DESIGN International, 26, pp. 3-20 is available online at: https://doi.org/10.1057/s41289-020-00144-4 


\section{Developing an Analytical Framework for Liveable Streets in Shanghai}

Aura-Luciana Istrate ${ }^{\mathrm{a}, *}$; Fei Chen ${ }^{\mathrm{b}}$; Paul Kadetz ${ }^{\mathrm{a}, 1}$; Ying Chang ${ }^{\mathrm{a}}$; Austin Rhys Williams ${ }^{\mathrm{a}, 2}$;

a Xi'an Jiaotong-Liverpool University (XJTLU), 111 Ren'ai Road, Suzhou Industrial Park, Suzhou, Jiangsu Province, P. R. China, 215123

${ }^{\text {b }}$ University of Liverpool, Foundation Building, Brownlow Hill, Liverpool, UK, L69 7ZX

Present addresses: ${ }^{1}$ Zhejiang University, Hangzhou, China, 310058; ${ }^{2}$ Kingston School of Art, Kingston upon Thames, UK, KT1 1LQ;

*Corresponding author: aura.1.istrate@gmail.com; 


\title{
Developing an Analytical Framework for Liveable Streets in Shanghai
}

\begin{abstract}
This research explores how to understand the concept of 'liveable streets' in the context of Shanghai. It follows the Chinese State Council's call (2015) for ungated communities and dense street networks, meant to improve liveability in cities. Factors of liveability have been extracted from both the international and Chinese literature and refined through locally-administered online questionnaires $(n=95)$ and semi-structured interviews $(n=12)$ with a sample of urban studies professionals. The outcome of this research is an analytical framework consisting of qualities, factors and indicators to assess and distinguish what constitutes a liveable street in Shanghai. A minimal set of 28 indicators is proposed to facilitate the straight-forward application of the framework in fast-growing urban settings. This research reveals the importance of contextualizing liveability factors and their relevance in informing policy-making and the practice of urban design and planning in Chinese cities.
\end{abstract}

Key-words: liveable streets; Shanghai; analytical framework; liveability. 


\section{Introduction}

Urban liveability appears frequently in governmental agendas as an objective to be achieved by providing adequate services and suitable living conditions in cities, and by attracting economic and social capital to urban areas (see The Liveability Agenda for the $21_{\text {st }}$ Century, World Bank, 1996). In 2015, the Chinese State Council advocated for building liveable cities (ý́ jū chéngshì, 宜居城市) in the country's ongoing urbanisation process (People's Daily, 2015). Nevertheless, the western concept of liveability has no clear or agreed-upon definition (Balsas, 2004; van Kamp et al, 2003; Pacione, 2003). Rather it is believed that liveability may imply different spatial qualities in different contexts and at different levels of analysis of countries, communities or residential streets (Istrate, 2016; Liu and Wang, 2013; Mandhar and Watt, 2011; Southworth, 2016).

In China, few attempts have been made to assess and rank liveable cities; for instance the 'Liveable City Assessment Standard' was released by the Ministry of Housing and Urban-Rural Development (MOHURD) in 2007 (Wang et al, 2011). However, such assessments predominantly employed criteria from the West, and did not consider local Chinese contexts. In particular, the criteria that make a street liveable (and suitable to live on) remains an unsolved question in China.

China has intensely promoted motorisation to stimulate economic development, and since the 1990s the number of motor vehicles has increased tenfold in Chinese cities (Cheng et al, 2007; Pucher et al, 2007). As a result, many residential streets were transformed into wide traffic arteries, and the social role of streets as public spaces was ignored (Yu, 2012). Only since 2015 has the State Council recognised that problems of car dependency and social segregation are associated with super blocks and gated communities, which became urban norms since the 1980s (Liu et al, 2014). The Council 
thus advocated to remove gates and fences in new developments and let streets and open spaces have an active social life.

In the international literature, the social attributes of streets have been extensively emphasised for liveability (Appleyard and Lintell, 1972; Jacobs, 1961). A liveable street was conceptualised as being safe and exhibiting a strong sense of place (informed by its identity and social meaning to the residents), where dynamic social interaction occurs (Appleyard, 1981; Dumbaugh, 2005; Gehl, 1987; Jacobs, 1961; Montgomery, 1998). By contrast, the Chinese literature on streets has focused more on engineering issues, concerning traffic and technology. Nevertheless, a few scholars recently have recognized the need for a 'humanised environment' and 'humanised street spaces' (rénxìng huà de jiēdào kōngjiān, 人性化的街道空间), referring to places that are being lived in, which provide physical comfort to residents (Cha et al, 2014; Friedmann, 2007; Shanghai Street Design Guidelines, 2016). Furthermore, the importance of the local economy has often been emphasised in Chinese street studies, in addition to access to public facilities and services (Cha et al, 2014; Du et al, 2012; Qin et al, 2003; Tongji, 2019). A sense of belonging, in which a resident feels integral to their social environment, was also recently promoted in China (Cha et al, 2014; Qin et al, 2003). Finally, a few Chinese scholars called for 'humanistic care' (rénwén guānhuái, 人文关怀), by considering aspects of safety and social interaction such as harmony among residents (Cha et al, 2014; Du et al, 2012).

However, no comprehensive framework of liveable streets has been identified in the literature. At first, Appleyard and Lintell (1972) formulated five indicators to assess liveable streets, which were further expanded in other studies (Bosselmann et al, 1999; Sanders et al, 2015). These studies focused primarily on the impact of automobiles on 
social interaction. Other frameworks of indicators were developed to assess sustainable transport (Castillo and Pitfield, 2010; Clifton et al, 2007) and how walking behaviours are affected by urban design qualities (Ewing and Clemente, 2013) or by businesses on streets (Mehta, 2008). Hence, studies which altogether consider the physical, functional and social characteristics of streets are scarce (Harvey and Aultman-Hall, 2016; Kim, 2015; Mehta, 2008).

In China, Cha et al (2014) compiled a list of principles for liveable streets from the international literature, but without validation through contextual research. Similarly, Shanghai's local government was the first to publish a design guideline for urban streets (the Shanghai Street Design Guidelines, 2016), with clear references made to Western examples, but without a systematic study carried out to examine and test the liveability of Shanghai's streets. Establishing a contextual framework of liveable streets informed by local stakeholders, and validated through field research is therefore necessary. This research addresses this gap and sheds light on the development of liveable streets in Chinese settings. The research findings corroborate and further develop the liveable streets attributes from the literature, which are elaborated through contextualised factors and indicators.

\section{Methods and Overview of Results}

A literature review of journal articles and policy documents from the Western and Asian literature (with a focus on China) was conducted. The sample was accessed from major international and Chinese databases, including the Web of Science, Google Scholar, China National Knowledge Infrastructure (CNKI), and China Academic Journals (CAJ). Documents with the terms 'liv(e)ability', 'liv(e)able streets', and the 
Chinese equivalent terms “宜居性” (yí jū xìng) and “宜居的街道” (yí jū de jiēdào) in title, abstract or key words were collected and reviewed. The relevant attributes were identified and summarised.

Subsequently, a self-administered online questionnaire was distributed in June 2016, targeting different categories of professionals working in urban studies. Ninety-five complete responses were obtained, of which nearly $70 \%$ were received from practising architects and planners in Shanghai. The questionnaire asked informants to first define liveability in the context of Shanghai and to verify the attributes of liveability extracted from the literature (formulated as six Likert-scale questions). Furthermore, informants were asked to indicate what they considered to be other significant variables affecting liveable streets in Shanghai. In-depth semi-structured interviews, using a similar schedule, were conducted with 6 academics and 6 real-estate developers to supplement the responses received from these two categories of professionals. The qualitative data was analysed with Nvivo 10, and the quantitative data was analysed with SPSS 24 .

The majority of respondents were from Mainland China (53.3\%) and worked in Shanghai (81.4\%). Other demographic data of informants is presented in Table 1. 
Table 1. Demographics of the Study Sample $(n=107)$

\begin{tabular}{lcc}
\hline Category & Frequency & Percentage of Total Sample \\
\hline Nationality & & \\
Mainland China & 57 & $53.3 \%$ \\
Other Asian Country & 6 & $5.6 \%$ \\
$\quad$ Non-Asian Country & 44 & $41.1 \%$ \\
Working location & & \\
Shanghai & 87 & $81.4 \%$ \\
Other place in China & 10 & $9.3 \%$ \\
Not in China/Recently left & 10 & $9.3 \%$ \\
Working experience & & \\
< 5 years & 40 & $37.4 \%$ \\
5-10 years & 26 & $24.3 \%$ \\
10-20 years & 27 & $25.2 \%$ \\
$\quad$ 20 years & 14 & 13.1 \\
Type of work & & \\
Research in academia (urban & 26 & $24.3 \%$ \\
studies/architecture/planning) & & \\
Practice in architecture/urban & 64 & $59.8 \%$ \\
design and planning & & \\
Other practice (including real estate) & 17 & $15.9 \%$ \\
\hline
\end{tabular}

Over $70 \%$ of informants who completed the questionnaire agreed or strongly agreed with the attributes extracted from literature (Figure 1). The calculated Cronbach Alpha for the respective Likert-scale questions $(\alpha=.809)$, demonstrates good internal consistency. No significant difference was found between the answers of Mainland Chinese and non-Chinese informants - as shown in the t-test for two independent samples $\mathrm{t}(93)=.372, \mathrm{p}=.711$ and the Chi-square test when cross-tabulating the median with the division of the two sample groups $\chi 2(1, \mathrm{~N}=95)=4.238, \mathrm{p}=.645$, which were of no statistical significance. 


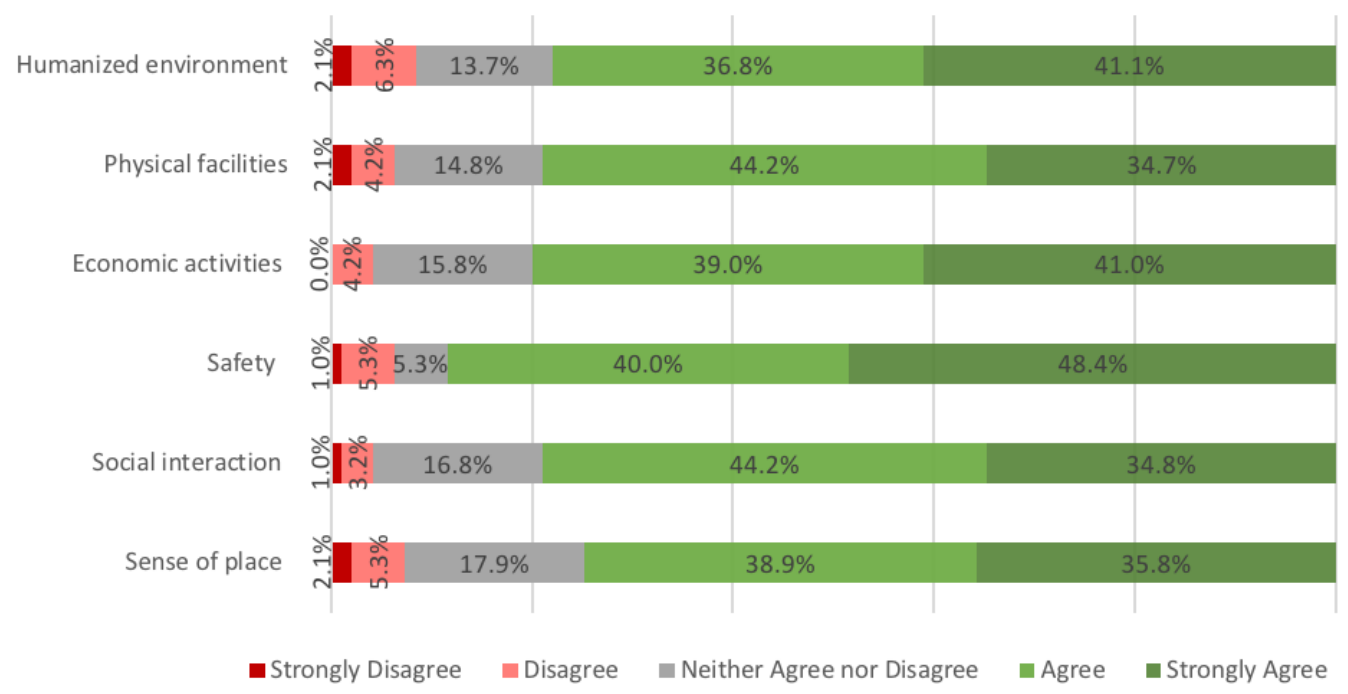

Figure 1: Concurrence with liveability attributes in questionnaires

The most frequently mentioned factors of liveable streets in Shanghai on questionnaires were, in order of frequency, traffic, green space, transportation, and accessibility. All other factors mentioned by informants were compiled under the six liveability attributes extracted from the literature: a humanised environment, physical facilities for living, economic activities, safety, social interaction, and sense of place. Other complementary factors and indicators have been further extracted through a focused review of literature on the six liveability attributes, as the informants' answers were not exhaustive (Table 2).

The validity of the six attributes forming an analytical framework (Table 3) has been tested through a comprehensive field study conducted on selected Shanghai streets, consisting of systematic observations and interviews with residents. This article, however, will only present the analytical framework with a few examples of its application in the field. 


\section{Attributes of Liveability}

This section discusses the findings from the study with professionals in relation to the focused literature regarding the six attributes of liveability (i.e. a humanised environment, physical facilities for living, economic activities, safety, social interaction, and sense of place).

\section{A Humanised Environment}

In the Western literature, streets that accommodate different modes of transport and multiple street users have been understood to be safer and more liveable (Dumbaugh, 2005; Dumbaugh and King, 2018). Recent studies have demonstrated that, compared to one-way streets, two-way streets can counteract commuter rush and reduce traffic collisions (Riggs and Gilderbloom, 2015). In contrast to the West, where the growing tension between cars and pedestrians was highly contested (since Appleyard and Lintell's study, 1972), mass motorisation has been more tolerated in China (Pucher et al, 2007).

Sample informants emphasised how the 'access to [diverse] transit options', 'connectedness' and 'commuting distance and time' affect liveability in Shanghai. The key words 'access', 'connect', and 'commute' were mentioned by nearly $50 \%$ of informants. This was consistent with the literature emphasising good accessibility, connectivity and an efficient transportation system (Cha et al, 2014; Du et al, 2012; Feng et al, 2008; Qin et al, 2003). A particular issue commonly mentioned by informants was that electric bicycles and scooters cause traffic conflicts in Shanghai.

The positive ambiance associated with street trees and vegetation was mentioned in both the international and Chinese literature (Cha et al, 2014; Jacobs, 1995), and it was a particular concern for $12 \%$ of informants. Although organised on very wide transversal 
profiles, contemporary streets in China feature wide greenbelts for both aesthetic and ecological benefits (Cheng et al, 2007).

Moreover, morphological characteristics of buildings and blocks affect the liveability of streets (Harvey and Aultman-Hall, 2016; Jacobs, 1961; Mahmoudi et al, 2014). The crucial importance of short blocks in enabling more comfortable walking (Jacobs, 1961) has been recently corroborated in the Chinese context as well (Cha et al, 2014; Qin et al, 2003). Furthermore, street frontages were shown to have a major effect on the pedestrian experience (Ewing and Clemente, 2013; Montgomery 1998), and the Western literature places emphasis on the way streetscapes are perceived by pedestrians (Harvey and Aultman-Hall, 2016; McAndrews and Marshall, 2018; Park and Garcia, 2019). In Shanghai, several informants highlighted the importance of having 'beautiful, narrow, [and] green streets', as well as 'streets [that] are clean, green, and most importantly, are [built] at human scale'. Furthermore, academic informants emphasised the need to preserve the traditional Chinese style of buildings flanking the streets. Assessing how various physical and morphological characteristics of streets affect liveability in non-Western contexts is necessary.

\section{Physical Facilities}

Complementing primary residential and office land uses, secondary uses (such as cafes and kiosks) are able to engage pedestrians and generate a diverse street life (Jacobs, 1961; Montgomery, 1998). The Chinese literature is particularly concerned with the quality of facilities and amenities in traditional areas, and the amount of amenities in newly built residential areas (Yu, 2012; Qin et al, 2003; Tongji, 2019; Yuan, 2005). 
Recent studies show that higher building densities enable higher access to facilities and services (Lang et al, 2019).

Thirty percent of informants indicated the need to have 'various', and 'abundant amenities' on Shanghai streets, that include community centres, sport fields, parks and art galleries, located within 'walking distance' or 'within $1 \mathrm{~km}$ ' radius from one's residence. Having a variety of services and amenities ensures a satisfactory living according to some informants in this study. Overall, the variety of cultural, educational, leisure, health and sport facilities, as well as the 'right mix of business and residential uses' were believed to be significant. In addition, an 'equal distribution of resources among social classes' was mentioned by some informants, because some amenities are not accessible to migrants or low-income groups.

Furthermore, Chinese cities have been confronted with issues of inadequate green areas and pollution (Gaubatz, 2008; Orum et al, 2009; Shanghai Street Design Guidelines, 2016; Yuan, 2005), but the importance of green belts adjacent to streets was acknowledged in recent studies (Tongji, 2019). In fact, $42 \%$ of informants in this research indicated that more green space is needed in Shanghai: not only in the form of street greenery, but also as 'green plot ratio' in residential developments, and as increased access to green spaces in proximity to one's home. Green spaces adjacent to residential streets should therefore be considered in analysis.

\section{Economic Activities}

The literature states that local economic activities give people reasons to linger on streets, and are thereby important for revitalising communities and street life (Jacobs, 1961; Mehta, 2008; McAndrews and Marshall, 2018; Whyte, 1980). The relevant Chinese 
literature places even stronger emphasis on how businesses and commercial activities give character to a street (Cha et al, 2014; Greenspan, 2017; Qin et al, 2003; Tongji, 2019). Indeed, 33\% of informants considered it was important to have 'local shops', 'active stores', and 'convenience of shopping [and] dining', as well as good 'access to restaurants [and] retail'. Informants emphasised the need to support small businesses on Shanghai's streets, as opposed to 'shopping malls', since building large-scale, branded commercial centres has been detrimental to local businesses in Shanghai (Gaubatz, 2008). In addition, some informants also indicated how the design of 'shop frontages' and 'display windows' can affect the pedestrian experience. They also highlighted the importance of a 'good environment to start new businesses', and indicated how 'the business opportunities make this city attractive to new residents'.

Different opinions about informal vendors can be found in the literature and in the findings of this study. In Asian contexts, it is argued that street markets and informal vendors bring liveliness to streets, and strengthen the local economy (Kim, 2015; Oranratmanee and Sachakul, 2014; Sivam and Karupannan, 2013). Similarly, some academics in China regard informal vendors as part of the Chinese culture (Greenspan, 2017; Friedmann, 2007). However, the government makes constant efforts to eliminate the informal economy on streets (Friedmann, 2007). Some informants believe that vendors negatively affect liveability by adding crowdedness to streets; others, however, recognise the importance of a 'free market' on Shanghai's streets. To determine how informal economic activities affect liveability on residential streets, contextual assessment is needed. 


\section{Safety}

Safety is a major concern in the Western literature, including crime prevention in public spaces (Hillier, 2004; Jacobs, 1961; Park and Garcia, 2019) and traffic hazard reduction (Appleyard and Lintell, 1972; Dumbaugh, 2005; Riggs and Gilderbloom, 2015). In Shanghai, 27\% of informants mentioned 'safety' as an important liveability factor.

Concerning traffic hazards, Appleyard (1981) demonstrates the negative correlation between vehicular traffic and social activities, and argues for reduced automobile use and increased traffic-calming elements on residential streets. This idea was reinforced by other international researchers (Appleyard and Cox, 2006; Hart and Parkhurst, 2011; Mahmoudi et al, 2014), but has scarcely been tested in China. Nevertheless, informants in this research indicate the need for a 'correct use of the street space', referring particularly to bike-riding on pavements, which can negatively affect safety in pedestrian areas, especially for children. The literature also confirms that on Shanghai's streets, the most frequent collisions occur between cars and bicycles or ebikes (Deng et al, 2013).

Regarding safety from crime, having 'eyes on the streets' is an effective way to achieve safety (Jacobs, 1961). Building on similar arguments, Hillier (2004) demonstrates that traditional street patterns are the most advantageous for safety, because they are better integrated into the street network and provide more opportunities for natural surveillance. For overall perceived safety, the variety of activities that induce human movement proved to be more important than minor incivilities (Park and Garcia, 2019). In Shanghai, some informants mentioned the problem of 'mugging', and the desire for 'properly secured' living and working places next to streets. Nevertheless, many other informants considered 
the city to be very safe because of the unceasing street activities throughout the day. Analysing safety in different residential areas of Shanghai is necessary, since contemporary compounds are gated, with buildings distanced from the street, whilst buildings in traditional areas have no setbacks and streets are aligned with small shops, which enable street life to flourish (Xie, 2012).

\section{Social Interaction}

The literature identifies how the presence of people attracts more people (Jacobs, 1961; Whyte, 1980), and how the physical environment can influence the type and intensity of outdoor activities (Gehl, 1987). Recent studies show that residents seem less aware of traffic volumes on streets with vibrant social functions (McAndrews and Marshall, 2018). Furthermore, scholars argue that too many restrictions or rules could negatively affect liveability (Gallent and Wong, 2009; Stevens, 2009). Yet, in China, public spaces that can be accessed and used freely by all are rare (Orum et al, 2009). Restricted access and the strict control of public spaces often result in impersonal and intimidating spaces in Chinese cities (Miao, 2011).

In this research, $24 \%$ of informants mentioned the words 'people' or 'residents' in reference to a subjective perception of liveability and to how the built environment should respond to 'people's needs', whilst simultaneously complaining that 'too many people' are overcrowding Shanghai's streets. The issue of 'migrant workers' (nóngmín gōng, 农民工 - rural dwellers who come to urban areas for work) was also mentioned. Though some informants perceived migrant workers as the cause of conflicts among neighbours, others called for 'social tolerance' and for 'harmony in communities'. In the literature, integrating migrant workers into city life was stressed as a key task in China's 
urbanisation (Friedmann, 2007; Orum et al, 2009). Informants further linked liveability to a 'richness' of 'playful activities' that take place on streets, as well as providing available 'socializing' places, for 'people [to] meet friends and relax'.

\section{Sense of Place}

The concept of 'sense of place' has been emphasised in Western contexts and is shaped by lived experiences, sensory perception, evidences of the past, and physical elements with distinctive characteristics (Carmona et al, 2010; Montgomery, 1998). In Chinese, this concept is more accurately translated as a 'sense of belonging' or 'place attachment' (guīshǔ găn, 归属感). Recent Chinese studies highlighted the importance of a sense of belonging to reflect the history of place and people's culture (Cha et al, 2014; Du et al, 2012).

Informants indicated the importance of respecting 'the [local] culture', and preserving the original features and identity of narrow streets. Informants also commented on issues such as the tidiness of residential streets and the need for improved sanitation. Overall, $27 \%$ of informants mentioned issues related to culture, identity and community hygiene.

Table 2 summarises the six attributes of liveability, with hierarchically organised factors and indicators extracted from the informant interviews and from the literature. We acknowledge that some factors are inevitably overlapping, but for clarity, we paired them with the most relevant indicators. 
Table 2: List of Liveability Attributes, Factors and Indicators

\begin{tabular}{|c|c|c|c|c|}
\hline $\begin{array}{l}\text { Attributes in } \\
\text { Literature }\end{array}$ & $\begin{array}{l}\text { Factors Emphasised by } \\
\text { Informants }\end{array}$ & $\begin{array}{l}\text { Complementary Factors } \\
\text { in Literature }\end{array}$ & Relevant Indicators in Literature & Relevant Studies \\
\hline \multirow[t]{3}{*}{$\begin{array}{l}\text { Humanised } \\
\text { Environment }\end{array}$} & $\begin{array}{l}\text { Accessibility; } \\
\text { Connectivity; } \\
\text { Convenient transport; } \\
\text { Traffic; }\end{array}$ & $\begin{array}{l}\text { Roadway configuration; } \\
\text { Motorized traffic; Traffic } \\
\text { control; }\end{array}$ & $\begin{array}{l}\text { accessibility to public transport; distance to } \\
\text { transit; street density; intersection density; } \\
\text { spatial accessibility; traffic volumes; traffic } \\
\text { speeds; traffic composition; number of car lanes; } \\
\text { single vs. dual carriageway; carriageway width; } \\
\text { roadway conditions; intersection types; traffic } \\
\text { control devices; parking space; curb cuts; cycling } \\
\text { paths; cyclists flows; noise and pollution from } \\
\text { traffic; }\end{array}$ & $\begin{array}{l}\text { Appleyard and Lintell, 1972; } \\
\text { Carmona, 2014; Clifton et al, 2007; } \\
\text { Dumbaugh and King, 2018; Ewing } \\
\text { and Cervero, 2010; Ewing and } \\
\text { Clemente, 2013; Hillier, 2014; } \\
\text { Marshall and McAndrews, 2017; } \\
\text { Riggs and Gilderbloom, 2015; } \\
\text { Sanders et al, 2015; Shanghai Street } \\
\text { Design Guidelines, 2016; }\end{array}$ \\
\hline & $\begin{array}{l}\text { The pedestrian } \\
\text { environment; Walking } \\
\text { distances; Walkability; } \\
\text { Street greenery; }\end{array}$ & $\begin{array}{l}\text { Slow traffic; Way-finding; } \\
\text { Environmental quality of } \\
\text { city streets; }\end{array}$ & $\begin{array}{l}\text { pavement width; walkway conditions; crossing } \\
\text { aids; facilities for the disabled; buffers and } \\
\text { barriers; obstructions; street furniture; } \\
\text { streetlights; street vegetation; street trees; } \\
\text { proportion of shaded pavements; }\end{array}$ & $\begin{array}{l}\text { Appleyard and Lintell, 1972; } \\
\text { Carmona, 2014; Clifton et al, 2007; } \\
\text { Ewing and Clemente, 2013; Fauzi } \\
\text { and Aditianata, 2018; Jacobs, 1995; } \\
\text { Sanders et al, 2015; Tongji, 2019; }\end{array}$ \\
\hline & $\begin{array}{l}\text { Aesthetics (the image } \\
\text { of the street); Street } \\
\text { space design; }\end{array}$ & $\begin{array}{l}\text { Architectural styles of } \\
\text { buildings; Urban form; } \\
\text { Perceptual urban design } \\
\text { features; }\end{array}$ & $\begin{array}{l}\text { historical period of development (old vs. new } \\
\text { buildings); building coverage; floor area ratio } \\
\text { (FAR); block dimensions; block permeability; } \\
\text { entrances and lanes; setbacks; building heights; } \\
\text { building height to street width ratio; continuity of } \\
\text { frontages; human scale; enclosure; complexity; } \\
\text { transparency; coherence; linkage; landmarks; } \\
\text { imageability; legibility; }\end{array}$ & $\begin{array}{l}\text { Bosselmann et al, 1999; Carmona, } \\
\text { 2014; Cha et al, 2014; Clifton et al, } \\
\text { 2007; Ewing and Clemente, 2013; } \\
\text { Llewelyn-Davis, 2000; Mahmoudi et } \\
\text { al, 2014; Montgomery, 1998; Jacobs, } \\
\text { 1961; Sanders et al, 2015; Shanghai } \\
\text { Street Design Guidelines, 2016; }\end{array}$ \\
\hline
\end{tabular}




\begin{tabular}{|c|c|c|c|c|}
\hline \multirow[t]{2}{*}{$\begin{array}{l}\text { Physical } \\
\text { Facilities for } \\
\text { Living }\end{array}$} & $\begin{array}{l}\text { Access to utilities, } \\
\text { services, and facilities } \\
\text { for living; }\end{array}$ & $\begin{array}{l}\text { Quality of facilities; } \\
\text { Amount of facilities; } \\
\text { Mixed-use; Primary and } \\
\text { secondary uses; }\end{array}$ & $\begin{array}{l}\text { accessibility to services; amenities on streets; } \\
\text { land uses along streets; ground floor uses; shop } \\
\text { fronts; active frontages; facility convenience; }\end{array}$ & $\begin{array}{l}\text { Carmona, 2014; Cha et al, 2014; } \\
\text { Clifton et al, 2007; Ewing and } \\
\text { Clemente, 2013; Jacobs, 1961; Lang } \\
\text { et al, 2019; Mehta, 2007; } \\
\text { Montgomery, 1998; Qin et al, 2003; } \\
\text { Sanders et al, 2015; Tongji, 2019; }\end{array}$ \\
\hline & $\begin{array}{l}\text { Parks in proximity; } \\
\text { Green recreational } \\
\text { spaces; }\end{array}$ & $\begin{array}{l}\text { Green belts; Permeable } \\
\text { surfaces; }\end{array}$ & $\begin{array}{l}\text { green ratio; green coverage; types of green } \\
\text { spaces; distance to parks; }\end{array}$ & $\begin{array}{l}\text { Cheng et al, 2007; Gaubatz, 2008; } \\
\text { Montgomery, 1998; Miao, 2011; } \\
\text { Shanghai Street Design Guidelines, } \\
\text { 2016; Tongji, 2019; }\end{array}$ \\
\hline \multirow[t]{2}{*}{$\begin{array}{l}\text { Economic } \\
\text { Activities }\end{array}$} & $\begin{array}{l}\text { Richness of local } \\
\text { economic activities; } \\
\text { Local shops; Free } \\
\text { market; }\end{array}$ & $\begin{array}{l}\text { Local businesses; } \\
\text { Strengthened local } \\
\text { economy; Informal } \\
\text { vendors; Street markets; }\end{array}$ & $\begin{array}{l}\text { commercial distribution; variety of businesses } \\
\text { (types, sizes); number of locally owned shops; } \\
\text { spatial arrangement of street markets; informal } \\
\text { economic activities; illegal economic activities; }\end{array}$ & $\begin{array}{l}\text { Carmona, 2014; Greenspan, 2017; } \\
\text { Kim, 2015; Mehta, 2007; } \\
\text { Oranratmanee and Sachakul, 2014; } \\
\text { Sivam and Karupannan, 2013; Qin et } \\
\text { al, 2003; Tongji, 2019; Xie, 2012; }\end{array}$ \\
\hline & $\begin{array}{l}\text { Opportunity to start } \\
\text { new businesses; }\end{array}$ & $\begin{array}{l}\text { Commercialisation; } \\
\text { Business networks; } \\
\text { Entrepreneurship and } \\
\text { start-up; e-commerce; }\end{array}$ & $\begin{array}{l}\text { commercial space rentals; business hours; local } \\
\text { profits; business rates; (online) customers; }\end{array}$ & $\begin{array}{l}\text { Carmona, 2014; Kim, 2015; Mehta, } \\
\text { 2007; }\end{array}$ \\
\hline \multirow[t]{2}{*}{ Safety } & $\begin{array}{l}\text { Correct use of the } \\
\text { street space; }\end{array}$ & $\begin{array}{l}\text { Traffic hazards; Traffic } \\
\text { calming; Consideration of } \\
\text { all street users; }\end{array}$ & $\begin{array}{l}\text { traffic accidents; aggressive road users; response } \\
\text { to traffic rules; perceived safety from traffic; }\end{array}$ & $\begin{array}{l}\text { Appleyard and Lintell, 1972; } \\
\text { Appleyard and Cox, 2006; Riggs and } \\
\text { Gilderbloom, 2015; Sanders et al, } \\
\text { 2015; Tongji, 2019; }\end{array}$ \\
\hline & Secured, private areas; & $\begin{array}{l}\text { Safety from crime; People } \\
\text { watching ('natural } \\
\text { policing'); Psychological } \\
\text { comfort; Gated vs. Non- } \\
\text { gated communities; }\end{array}$ & $\begin{array}{l}\text { crime rates; security measures (CCTV cameras, } \\
\text { etc.); presence of police and street wardens; } \\
\text { facades with windows to the street; children } \\
\text { playing; graffiti; perceived safety from crime; }\end{array}$ & $\begin{array}{l}\text { Appleyard and Cox, 2016; Carmona, } \\
\text { 2014; Ewing and Clemente, 2013; } \\
\text { Gehl, 1987; Hillier, 2004; Jacobs, } \\
\text { 1961; Llewelyn-Davis, 2000; Park and } \\
\text { Garcia, 2019; Sanders et al, 2015; }\end{array}$ \\
\hline
\end{tabular}




\begin{tabular}{|c|c|c|c|c|}
\hline \multirow[t]{2}{*}{$\begin{array}{l}\text { Social } \\
\text { Interaction }\end{array}$} & $\begin{array}{l}\text { People exploring the } \\
\text { public space; People } \\
\text { interacting and } \\
\text { socializing; }\end{array}$ & $\begin{array}{l}\text { Human activity; Mix of } \\
\text { outdoor activity; Dynamics } \\
\text { of street life; Social } \\
\text { encounter and } \\
\text { interchange; }\end{array}$ & $\begin{array}{l}\text { human activities on streets (necessary, optional, } \\
\text { social); pedestrian volumes; number of friends } \\
\text { and acquaintances; formal and informal social } \\
\text { networks; demographics (age, gender, income, } \\
\text { education, length of residence; home ownership; } \\
\text { subculture origins; number of people in the } \\
\text { household; population density); }\end{array}$ & $\begin{array}{l}\text { Appleyard and Lintell, 1972; } \\
\text { Carmona, 2014; Cha et al, 2014; } \\
\text { Ewing and Clemente, 2013; } \\
\text { Friedmann, 2007; Gehl, 1987; } \\
\text { McAndrews and Marshall, 2018; } \\
\text { Montgomery, 1998; Orum et al, } \\
\text { 2009; Sanders et al, 2015; }\end{array}$ \\
\hline & $\begin{array}{l}\text { Available community } \\
\text { space; Public Space; }\end{array}$ & $\begin{array}{l}\text { Publicness; Free access for } \\
\text { all; Unrestricted use; } \\
\text { Seating arrangements; }\end{array}$ & $\begin{array}{l}\text { privatized vs. non-privatized spaces; restrictions; } \\
\text { outdoor (dining) tables and seats; }\end{array}$ & $\begin{array}{l}\text { Carmona, 2014; Gallent and Wong, } \\
\text { 2009; Gaubatz, 2008; Miao, 2011; } \\
\text { Orum et al, 2009; Sivam and } \\
\text { Karupannan, 2013; Whyte, 1980; }\end{array}$ \\
\hline \multirow[t]{2}{*}{ Sense of Place } & $\begin{array}{l}\text { Streetscapes with } \\
\text { identity; Culture; }\end{array}$ & $\begin{array}{l}\text { Lived experiences; } \\
\text { Evidences of the past; } \\
\text { Distinctiveness; Local } \\
\text { character; Local identity; }\end{array}$ & $\begin{array}{l}\text { elements with distinctive significance; sensory } \\
\text { perception; noise tolerance; home territory; } \\
\text { memory of place; }\end{array}$ & $\begin{array}{l}\text { Appleyard and Lintell, 1972; } \\
\text { Carmona, 2014; Carmona et al, } \\
\text { 2010; Cha et al, 2014; Ewing and } \\
\text { Clemente, 2013; Friedmann, 2007; } \\
\text { Gehl, 1987; Llewelyn-Davis, 2000; } \\
\text { McAndrews and Marshall, 2018; }\end{array}$ \\
\hline & $\begin{array}{l}\text { Stable and strong } \\
\text { community; }\end{array}$ & $\begin{array}{l}\text { Place attachment; } \\
\text { Belonging; Public } \\
\text { participation; }\end{array}$ & $\begin{array}{l}\text { local gatherings, events; maintenance, tidiness } \\
\text { and hygiene levels; }\end{array}$ & $\begin{array}{l}\text { Carmona, 2014; Cha et al, 2014; } \\
\text { Clifton et al, 2007; Ewing and } \\
\text { Clemente, 2013; Gehl, 1987; } \\
\text { Mahmoudi et al, 2014; McAndrews } \\
\text { and Marshall, 2018; Montgomery, } \\
\text { 1998; }\end{array}$ \\
\hline
\end{tabular}




\section{Establishing the Analytical Framework for Liveable Streets in Shanghai}

Considering that recent policies promote ungated residential communities and dense streets in Chinese cities, a framework of liveable streets that is pertinent to China is needed. The six 'attributes' extracted from literature and presented in Table 2 were reframed as 'qualities' in the analytical framework, to better reflect the positive influence they have on liveable streets. We added 'local' to the 'humanised environment' and 'economic activities', to specify the level of analysis of individual streets. Furthermore, the 'physical facilities for living' were integrated with the 'mix of uses', to capture the functional diversity of streets. The attribute of 'social interaction' was integrated with 'public life' to capture the overall human activity on streets.

Specific factors and indicators were formulated to measure the six liveability qualities in Shanghai. The following section explains the ways in which the analysis can be carried out using data available in China. Sample indicators are used to demonstrate the validity of the framework.

\section{The Local Humanised Environment}

This quality of liveability requires the physical space of the street to be convenient and comfortable for different categories of users. It can be measured through three factors. First, the 'Road and Transport Characteristics' concern the space for vehicular traffic. Extensive literature informs this factor through indicators that are directly measurable. Assessing traffic volumes is crucial - a key indicator in both Western and Asian liveable streets studies (Appleyard and Lintell, 1972; Sanders et al, 2015). Along with traffic composition and speeds, these indicators can be assessed using traffic-counting apps, speed-recording cameras or realtime traffic data (from companies such as DiDi Chuxing or Baidu Inc). Furthermore, 'distance 
to transit' is relevant especially when concerned with residential streets, and it can be analysed through transit stop buffers in GIS maps or through measuring the actual distances from residential streets to transit stops on open-source maps (e.g. Baidu Maps). Other indicators of road configuration and profiles can be examined through open-source street view imagery (Baidu Street View); nevertheless, it is recommended to verify the accuracy of such data through site visits.

Second, the 'Pedestrian Environment' reveals the conditions for walking and street greenery. All the proposed indicators of this factor (see Table 3) are straightforward and have been extensively presented in literature; they can be directly assessed through on-site physical surveys, as open data sources do not reveal detailed information. In microscale studies, thorough information concerning pavement materials, distances from curbs, obstructions, street bollards, etc. can be further obtained during site visits.

Third, the factor comprising 'Characteristics of Buildings and Blocks' covers indicators such as the mix of old and new buildings, block dimensions, setbacks, building heights, and building height to street width ratio. These can be directly assessed either through site observations, or using urban plans and maps.

Other indicators are not directly measurable, but can be assessed through professional, contextual judgement on selected streets. The degree of enclosure varies significantly among streets in Shanghai that were formed in different periods of the city's development (Figure 2). Besides building frontages, vertical elements such as trees and walls, can impact the degree of enclosure (Ewing and Clemente, 2013); however, the significance of their impact on wide contemporary streets bordered by high-rises needs to be further analysed in Shanghai. 

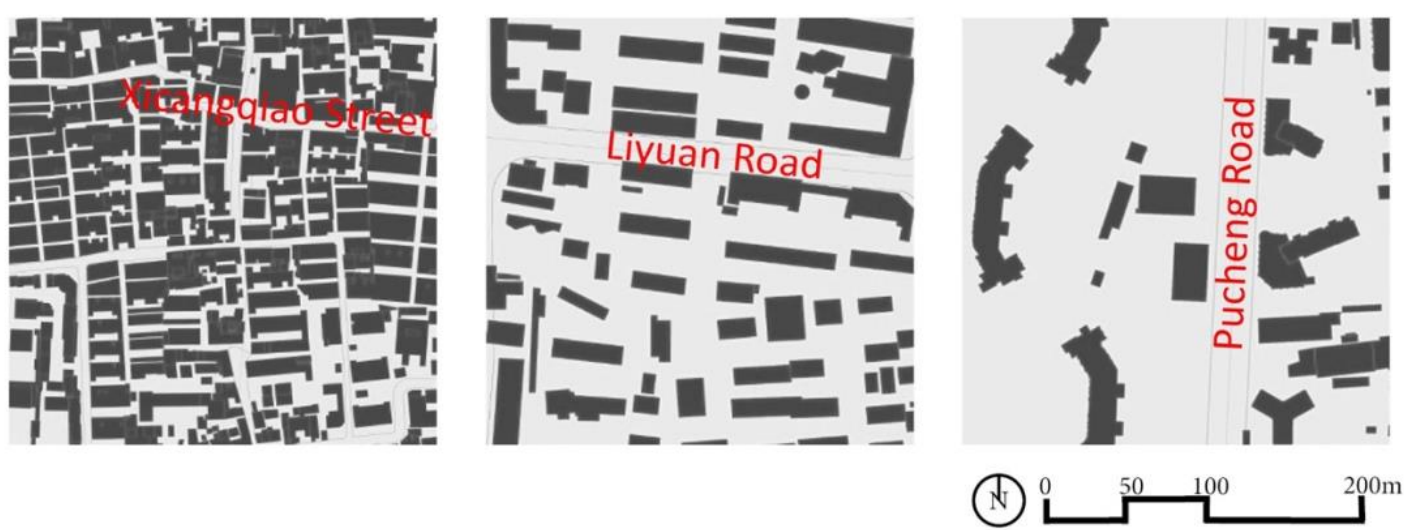

Figure 2: Examples of degrees of enclosure on Shanghai streets (built vs. unbuilt areas)

Shanghai has some highly uniform and monotonous streets, which are attributed to socialist planning (Qin et al, 2003). Thus, the degree of complexity becomes highly important. High building complexity is preferred as long as it does not become chaotic (Figure 3), which requires the assessors' judgement. Relevant aspects informing complexity usually include architectural stylistic elements, signage and landscape features, but in Shanghai, shop advertisements are also relevant, as mentioned by interview informants.
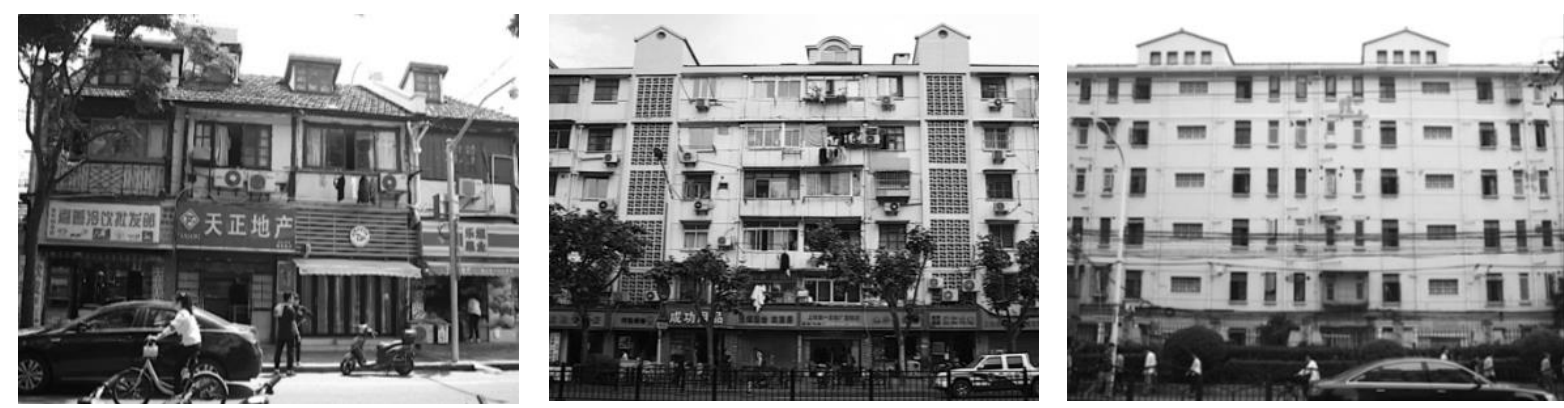

Figure 3: From high, to moderate, to low complexity (left picture: Jiashan Road in Puxi; middle and right picture: Rushan Road in Pudong, Shanghai)

The degree of transparency from the street refers to the extent to which people can perceive beyond the street edge, inside courtyards or buildings, especially in terms of human activities. In contrast to blank walls, see-through windows and glass facades, as well as trees, bushes, and entrances contribute positively to transparency by providing signs of habitation 
(Ewing and Clemente, 2013). In this framework, transparency is predominantly visual and experiential, which is not equivalent to access points (Figure 4).
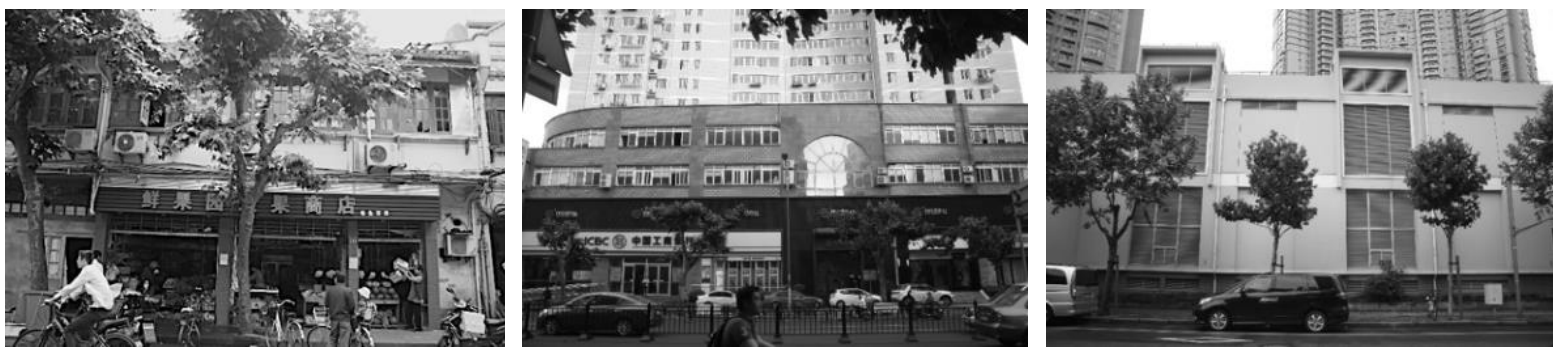

Figure 4: From high, to moderate, to low transparency (from left to right: Penglai Road and Xietu Road in Puxi, Pucheng Road in Pudong, Shanghai)

The 'human scale' refers to the dimensions of street frontages, street width and other elements of the built environment that are not overwhelming to humans. Elements such as trees, street furniture and building details, that can be captured by sight while walking, contribute positively to the perception of human scale. However, many Shanghai streets dating from the Socialist period (1949-1978) are quite broad, and are bordered by standardised buildings which feature limited architectural details that relate to human scale. Furthermore, accommodating high traffic volumes, contemporary streets are very wide as well, and are often bordered by high-rise buildings, overwhelming pedestrians (Figure 5).
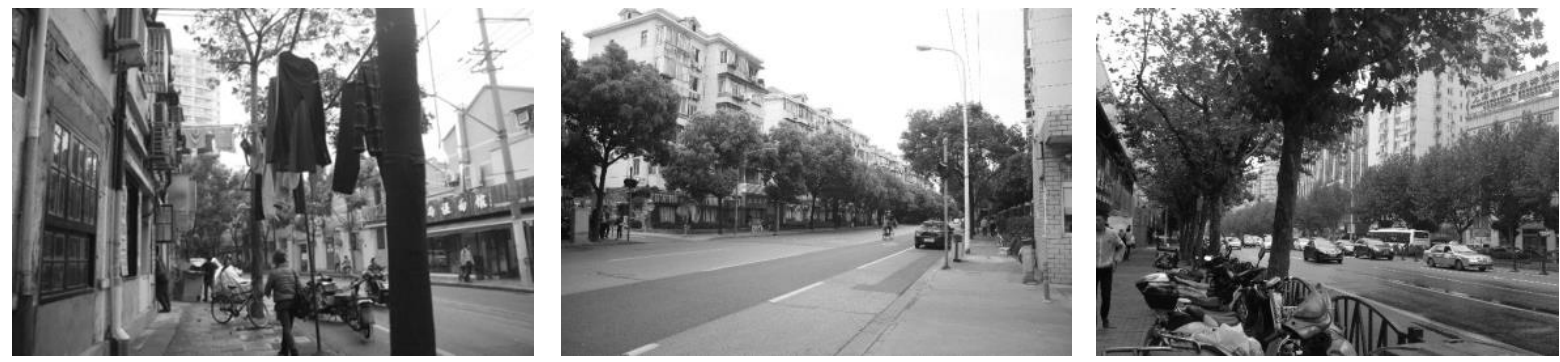

Figure 5: From human scale, to socialist, to automotive scales (from left to right: Jiashan Road in Puxi, Shangcheng Road and Pudong South Road in Pudong, Shanghai). 
Visual connections across streets can also contribute to a perceived linkage in the built environment (Ewing and Clemente, 2013), but in this framework, the linkage to the street simply refers to the number of entrances to residential buildings or to residential compounds within the length of a block, which offer residents direct access to streets. Having multiple access points for street users increases permeability within blocks, which is important considering that Shanghai has numerous superblocks (Figure 6).

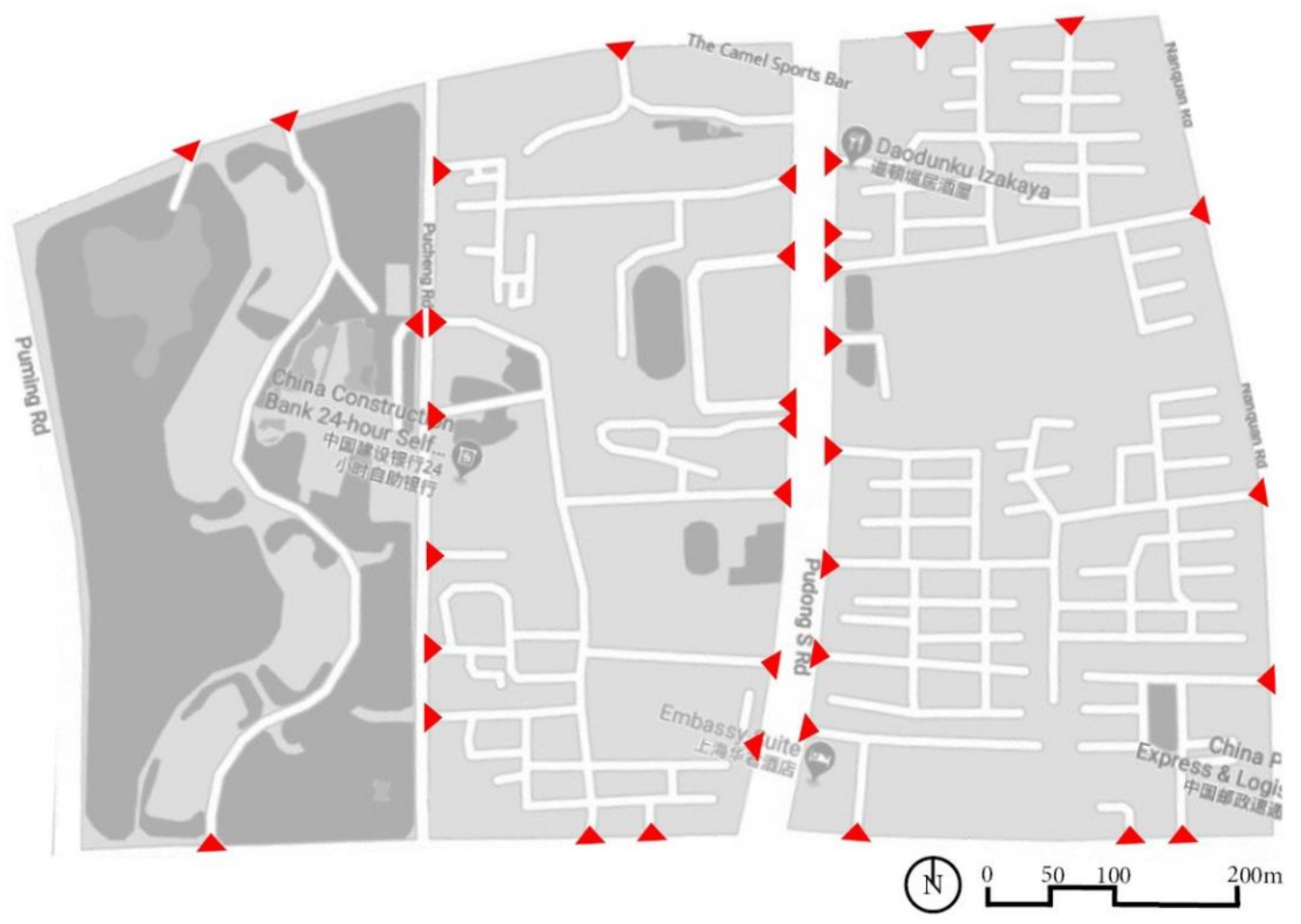

Figure 6: From very low, to moderate and higher linkage within three parallel urban blocks (Background map source: Google Maps 2019)

Open-source data from Baidu Maps and Baidu Street View can be used to analyse linkage, enclosure and human scale to some extent, but is not suitable to examine complexity and transparency which require judgement from the assessors. Furthermore, streetscapes 
change rapidly in China, therefore it is necessary to conduct frequent site visits in order to gain current data.

\section{Physical Facilities for Living and the Mix of Uses}

This quality comprises two main factors. The first factor concerns Land Uses, Services and Amenities. The analysis of secondary land uses in relation to primary land uses and their role in generating diverse activities on streets is important for Shanghai, because contemporary streets are largely bordered by mono-functional residential buildings, as opposed to traditional streets bordered by small stores (Qin et al, 2003; Xie, 2012). Assessing basic facilities of transport, water and sewage is necessary in the Chinese context, as they differ in areas that were built in different historical periods; other amenities to note on streets include those containing cultural and entertainment activities, mentioned by interview informants. These indicators can be analysed through maps, urban plans and GIS (geographic information systems) databases, but also through physical surveys.

Furthermore, the indicator of 'active ground floors' refers to businesses or retail uses that open directly onto the footpath. We define this indicator differently from the term 'active frontages' in the literature. The latter takes the whole building frontage into consideration, including all openings, façade rhythms and complexity (see for instance in the UK, LlewelynDavis, 2000). This is because in our analytical framework, façade elements are analysed within the Local Humanised Environment category. This indicator particularly focuses on available services and businesses on the ground floor of buildings bordering streets, which is important in the Chinese context. The 'active ground floors' indicator can be estimated during site visits.

Moreover, the quality of services and facilities on streets can be investigated through interviews with residents. 
Access to Green and Open Spaces and the issue of pollution were highly emphasised in the Chinese literature, as well as by informants. This factor can be assessed through green coverage - the percentage of green space within the blocks bordering residential streets. In addition, the distance from residential streets to public parks can be analysed based on urban plans, maps and satellite images.

\section{Local Economic Activities}

The opportunities of starting new business and the richness of economic activities emphasised by informants (Table 2) are related to Businesses on the Street in this analytical framework. Despite limited availability of tools to analyse the diversity of economic activities (Greenspan, 2017), the number of locally owned businesses on streets can be easily counted. Furthermore, the variety of businesses, the social classes to which they cater, and business hours provide useful information about the way businesses located near streets affect liveability in Shanghai. In microscale studies, commercial spaces available for rent and rental rates can be further analysed to inform the feasibility of starting new businesses. Such data can be collected from the archives of the property management bureau, or from the Street Office in China (juweihuì, 居委会). Finally, informal economic activities - a concern of the informants in this research - need to be included in the analysis by conducting site observations. This analysis can reveal whether informal vendors attract human activity on streets or cause disorder.

\section{Safety from Crime and from Traffic}

This quality is informed by three factors. A main factor derived from the research with professionals is the Correct Use of the Street Space, referring to safety from traffic. This factor comprises indicators of aggressive road users (e.g. drivers and bikers deliberately speeding) and their response to traffic rules, as traffic conflicts were recorded on Shanghai's streets (Deng et 
al, 2013). These indicators can be assessed through statistical data of traffic accidents, and through systematic observation.

The factor of Security Eyes on the Street refers to security measures provided by the local authorities (such as the presence of police officers, guards and security cameras) which differs from spontaneous people-watching on streets. This factor is highly relevant in Shanghai, because security guards of gated communities and extensive video surveillance networks are currently in use. Such measures can influence liveability positively if they ensure safety from crime, or negatively, if they promote an overly-controlled street space or result in access restrictions for lower social classes. These indicators can be assessed through site observations.

In addition, for the Perception of Safety, interviews or questionnaires with the residents are the best way to collect relevant data; given the prevalence of smart phones among Chinese residents today (Tongji, 2019), this type of data can be collected and geolocated through online means (e.g. using WeChat app). In the West, this factor can be assessed through the number and frequency of children playing on streets. But this would not work in Shanghai, because children playing on streets is not socially-acceptable for most families. Therefore, this factor can only be assessed through street users' survey.

\section{Social Interaction and Public Life}

Two factors are relevant to social interaction and public life. The analysis of Opportunities for Interaction can be carried out through three indicators. One is the presence of dining tables and outdoor seating, which provide space for interaction. In the international literature, this usually refers to designated spaces (e.g. in front of restaurants), but in the Chinese context, informal seating on residential streets is popular, thus it should be considered. Human activities need to be documented from early mornings to late evenings, in order to capture the rhythm of daily activities on Chinese streets. The third indicator refers to the number of friends, 
relatives and acquaintances that residents have living on the same street. This indicator has been used to determine social connections in both Western and Asian contexts, and can be investigated through interviews.

Concerning People on the Street, one common and relevant indicator is that of pedestrian volumes - the number of people passing by a street in a given time. Counting pedestrians would provide insights into the experienced human presence on streets, and can be done manually or with advanced technologies such as sensors, cameras or mobile phone data. Furthermore, the length of residence, home ownership, income and the number of people in households can be collected in questionnaires or from census records - such data is relevant since significant socio-demographic differences were found on streets that featured different traffic and liveability conditions in previous studies (Appleyard, 1981; Sanders et al, 2015).

\section{Sense of Place and Belonging}

The Identity and Culture on Streets is proposed as the main factor under this quality. Distinctive characteristics of the street environment, which are contextually-dependent, can firstly be documented. Furthermore, sensory stimuli (visual, olfactory, and auditory) influencing the perception of streets are relevant in the Chinese context, considering for instance the multitude of small restaurants bordering streets. Local gatherings can be documented to reveal insights on belonging and strengthening communities. Tidiness (cleanliness) is also important, as it can reveal the extent to which residents care for the space in which they live, and it can affect the desire of others to use the street. These indicators can be investigated through site observations. Subjective indicators include the 'memory of place' revealing the way residents picture their street and the 'home territory', concerning places where the residents feel comfortable as in their own home. These were central in liveable streets studies in both Western and Asian contexts. Other indicators related to public participation and the residents' 
involvement within communities are less relevant, since China has a less active civil society compared to the West (Friedmann, 2007; Orum et al, 2009). 
Table 3: Analytical Framework for Liveable Streets in Shanghai

\begin{tabular}{|c|c|c|}
\hline QUALITIES & FACTORS & INDICATORS \\
\hline \multirow{3}{*}{$\begin{array}{l}\text { LOCAL HUMANISED } \\
\text { ENVIRONMENT }\end{array}$} & $\begin{array}{l}\text { Road and transport } \\
\text { characteristics }\end{array}$ & $\begin{array}{l}\text { traffic volumes/ traffic speeds / traffic composition / } \\
\text { carriageway width / single vs. dual carriageway/ number } \\
\text { of car lanes/ cycling paths / traffic control devices / } \\
\text { parking space / distance to transit }\end{array}$ \\
\hline & $\begin{array}{l}\text { The pedestrian } \\
\text { environment }\end{array}$ & $\begin{array}{l}\text { pavement width / crossing aids / barriers and buffers / } \\
\text { street furniture/ streetlights / landscaping features on } \\
\text { streets/ street trees / proportion of shaded pavement }\end{array}$ \\
\hline & $\begin{array}{l}\text { Characteristics of } \\
\text { buildings and blocks }\end{array}$ & $\begin{array}{l}\text { historical period of construction (old vs. new buildings)/ } \\
\text { block dimensions / setback / building height / building } \\
\text { height to street width ratio / *enclosure / *complexity / } \\
\text { *transparency / *human scale / *linkage to the street }\end{array}$ \\
\hline \multirow{2}{*}{$\begin{array}{l}\text { PHYSICAL FACILITIES FOR } \\
\text { LIVING AND THE MIX OF } \\
\text { USES }\end{array}$} & $\begin{array}{l}\text { Land uses, services } \\
\text { and amenities }\end{array}$ & $\begin{array}{l}\text { land uses along streets / services and amenities on } \\
\text { streets / *active ground floors / *facility convenience }\end{array}$ \\
\hline & $\begin{array}{l}\text { Green and open } \\
\text { spaces }\end{array}$ & $\begin{array}{l}\text { green coverage / distance to parks in proximity to } \\
\text { residential streets }\end{array}$ \\
\hline $\begin{array}{l}\text { LOCAL ECONOMIC } \\
\text { ACTIVITIES }\end{array}$ & $\begin{array}{l}\text { Businesses on the } \\
\text { street }\end{array}$ & $\begin{array}{l}\text { locally owned shops/variety of businesses (types, sizes) / } \\
\text { business hours / informal economic activities }\end{array}$ \\
\hline \multirow{3}{*}{$\begin{array}{l}\text { SAFETY FROM CRIME } \\
\text { AND FROM TRAFFIC }\end{array}$} & $\begin{array}{l}\text { Correct use of the } \\
\text { street space }\end{array}$ & aggressive road users / the response to traffic rules \\
\hline & $\begin{array}{l}\text { Security eyes on the } \\
\text { street }\end{array}$ & $\begin{array}{l}\text { presence of police officers and security guards / security } \\
\text { cameras (CCTV) }\end{array}$ \\
\hline & Perception of safety & $\begin{array}{l}\text { *perceived safety from crime / *perceived safety from } \\
\text { traffic }\end{array}$ \\
\hline \multirow{2}{*}{$\begin{array}{l}\text { SOCIAL INTERACTION } \\
\text { AND PUBLIC LIFE }\end{array}$} & $\begin{array}{l}\text { Opportunities for } \\
\text { interaction }\end{array}$ & $\begin{array}{l}\text { outdoor (dining) tables and seats /*human activities on } \\
\text { the street / *number of friends and acquaintances }\end{array}$ \\
\hline & People on the street & $\begin{array}{l}\text { pedestrian volumes / length of residence / home } \\
\text { ownership / income / number of people in households }\end{array}$ \\
\hline $\begin{array}{l}\text { SENSE OF PLACE AND } \\
\text { BELONGING }\end{array}$ & $\begin{array}{l}\text { Identity and culture } \\
\text { on streets }\end{array}$ & $\begin{array}{l}\text { *elements of distinctive significance / *sensory } \\
\text { perception / tidiness of streets / *local gatherings / } \\
\text { *memory of place (picturing the street) / *home } \\
\text { territory (feeling at home) }\end{array}$ \\
\hline
\end{tabular}

Objective indicators are in italics; subjective indicators are in bold.

*indicators which require careful contextual interpretation. 
In summary, the factors in the analytical framework (Table 3) have been primarily derived from the data collected from professional informants. These factors provide a theoretical base to distinguish what constitutes a liveable street in Shanghai. Objective and subjective indicators are formulated, requiring different methods of analysis. The objective indicators can be analysed through physical surveys and direct observation. Most of the objective indicators are directly measurable; those that are not directly measurable (e.g. determining what constitutes a high, moderate or low degree of enclosure) require the objective judgement of observers. The subjective indicators which depend on residents' perception can be analysed through interviews and questionnaires. A rich graphical analysis to support design interventions or policy-making can emerge (Appendix 1).

The qualitative focus of this analytical framework can be more time-consuming compared to quantitative research, and leaves more room for interpretation, but is essential to capture comprehensive and contextually-relevant elements of liveable streets. Digital tools making use of big data and machine learning algorithms may be very useful when analysing and comparing large samples of street sites. Emerging research shows that digital tools are efficient in analysing street greenery or physical space variation (Long and Liu, 2017; Tang and Long, 2019; Ye et al, 2019). But the human experience, perceptions, attitudes, behaviours, social interaction and the overall dynamic of street life are best captured by human eyes and human understanding. The proposed analytical framework employs conventional qualitative methods along with digital tools for some indicators. In fact, we argue that a combination of qualitative and quantitative analysis would yield more complete results when assessing the liveability of streets.

Indicators from the vast Western literature were used where appropriate, particularly those indicators which can be directly measured. These indicators still require adaptation in relation to the local situation, because they depend on built forms (e.g. block dimensions, 
building height, etc.), functional uses (e.g. variety of businesses) or population densities (e.g. pedestrian volumes), which differ from Western contexts. Other indicators require more indepth contextual interpretation, including: subjective indicators capturing people's perceptions; as well as indicators reflecting the way the street is experienced in relation to specific building styles (e.g. enclosure, human scale), street functions (e.g. active ground floors), or sociopolitical situations (e.g. human activities allowed to take place on streets). These indicators have been reframed, and, as highlighted throughout this section, they require a nuanced interpretation via local understandings.

From the extensive analytical framework (Table 3), key indicators (28 out of 58 indicators in total) have been prioritized (Table 4) to facilitate a rapid and practical assessment of liveable streets. They have been listed directly under the six liveability qualities to reflect the theoretical findings of this research and to reduce the complexity of the framework when implemented in practice. The prioritized indicators primarily concern the street space itself (e.g. not including indicators such as 'distance to transit' or 'green coverage', which affect liveable streets in an indirect manner, as they are found beyond the street space itself). The importance of the key indicators was validated through subsequent field research with street informants. 
Table 4: A minimal set of key indicators of liveable streets

\begin{tabular}{|c|c|}
\hline QUALITIES & INDICATORS \\
\hline \multirow{3}{*}{$\begin{array}{l}\text { LOCAL HUMANISED } \\
\text { ENVIRONMENT }\end{array}$} & traffic volumes/ carriageway width / cycling paths / parking space \\
\hline & pavement width / crossing aids /street furniture/ streetlights / street trees \\
\hline & $\begin{array}{l}\text { block dimensions / setback / building height / *enclosure / *human scale / } \\
\text { *linkage to the street }\end{array}$ \\
\hline PHYSICAL FACILITIES FOR & land uses along streets (mixed-uses) / amenities on streets / *active ground \\
\hline LIVING AND THE MIX OF USES & floors \\
\hline LOCAL ECONOMIC ACTIVITIES & (number of) locally owned shops/variety of businesses (types, sizes) \\
\hline $\begin{array}{l}\text { SAFETY FROM CRIME AND } \\
\text { FROM TRAFFIC }\end{array}$ & $\begin{array}{l}\text { the response to traffic rules } /{ }^{*} \text { perceived safety from crime } /{ }^{*} \text { perceived } \\
\text { safety from traffic }\end{array}$ \\
\hline $\begin{array}{l}\text { SOCIAL INTERACTION AND } \\
\text { PUBLIC LIFE }\end{array}$ & *human activities on the street / pedestrian volumes / length of residence \\
\hline $\begin{array}{l}\text { SENSE OF PLACE AND } \\
\text { BELONGING }\end{array}$ & tidiness of streets / *memory of place (picturing the street) \\
\hline
\end{tabular}

Objective indicators are in italics; subjective indicators are in bold.

*indicators which require careful contextual interpretation.

\section{Conclusion}

A context-specific framework for liveable streets in Shanghai and China was absent. This research fills this gap by enriching the liveability qualities extracted from literature through questionnaires and interviews with professionals in China. The emerging framework was subsequently assessed by the authors in a comprehensive field study on fifteen selected streets in Shanghai. Although it is beyond the scope of this article to present the field outcomes, sample indicators were used to demonstrate the applicability of the framework. This framework organises the relevant qualities, factors and indicators of liveable streets into a hierarchical structure, making it easier to assess liveable streets (Table 3). A minimal set of indicators to adopt in practice has been put forth (Table 4). 
The six identified qualities in this study indicate that Liveable Streets in Shanghai are embedded in a Local Humanized Environment, with good Physical Facilities for Living and small-scale Mixed-Use, in which Local Economic Activities can flourish, and conditions for Safety, Social Interaction and Public Life, as well as Sense of Place and Belonging are satisfied and supported.

This research is primarily based on the case of Shanghai; it represents, however, a thorough study of liveable streets from an urbanistic perspective, which has not previously been done in China and which could benefit the national street design guidelines in preparation (announced in Tongji, 2019). With further exploration (e.g. concerning factors of 'opportunities for interaction', 'identity and culture', or 'characteristics of buildings and blocks'), this framework could be applied to other cities in different cultural and morphological regions of China.

The framework can be further developed by assigning weight of importance to each indicator. This will make it possible to quantify part of the analysis and helps decision-making for street improvement. Further research could extend the scope of the liveability analysis, to identify the role of a network of liveable streets in improving a city's liveability. This would render higher complexity to the framework, and may need extensive collaboration of academics, practitioners and policy-makers.

A limitation of this study was the small sample of professionals participating in semistructured interviews, and the insufficient number of government representatives. However, the close involvement of such stakeholders is essential for exploring the framework's potential in benefiting policy-making, recommended for future research.

This research highlights the importance of contextually defining factors and indicators prior to field assessments. As discussed in previous sections, particular characteristics of Chinese streets require a rethinking of what constitutes a 'liveable street'. Such characteristics 
include: the numerous active businesses on some residential streets; the dynamic flow of cyclists competing for street space with cars and pedestrians; as well as the social life which reflects specific social norms, altered by the presence of migrant workers and by security measures. These are some of the indicators in the framework that have been reinterpreted or newly introduced to better capture the understanding of liveable streets in this context. Many aforementioned Western studies focused on partial aspects of liveable streets such as: the effect of motorized traffic on social aspects; how walking is affected by elements of the built environment; or the commercial prospect of main streets. Limiting an examination to such aspects would not be effective in revealing an overall understanding of liveability in China. Assessing altogether physical, functional and social aspects of streets provides a new theoretical basis for liveable streets in China, and avoids adopting Western principles blindly.

Approximately one quarter of the indicators in this framework capture the contextual, indirectly-measurable and subjective understanding of liveability (see Table 3), which supports an understanding that the liveability concept cannot be entirely standardised or universalised. As such, liveability becomes a nuanced concept: the international discourse does not need to be tossed, however, some aspects of liveable streets commonly apply, while others need to be locally identified.

This article demonstrates that research on liveable streets must primarily be exploratory in nature, involving local stakeholders, and fully considering local conditions. A similar research process could be replicated to inform the necessary interpretation of liveable streets indicators in other parts of the world, for example in emerging cities in South-East Asia, Middle-East, or Africa. This not only concerns social indicators (e.g. memory of place, human activities taking place on streets), but also other physical or functional indicators (e.g. building complexity, active ground floors, etc.). While much can be learned from the West, we suggest more reflection on local specificities and social practices for liveable streets. It is inadequate to 
superimpose the Western framing of liveable streets without addressing contextual understandings. Only by a reinterpretation of indicators and their significance to local contexts can Western-originated concepts, such as 'liveability', be employed in non-Western settings. This research contributes to such an effort by contextualising the concept of liveable streets in Shanghai. 
Appendix 1: Graphical Analysis of Indicators in the Analytical Framework
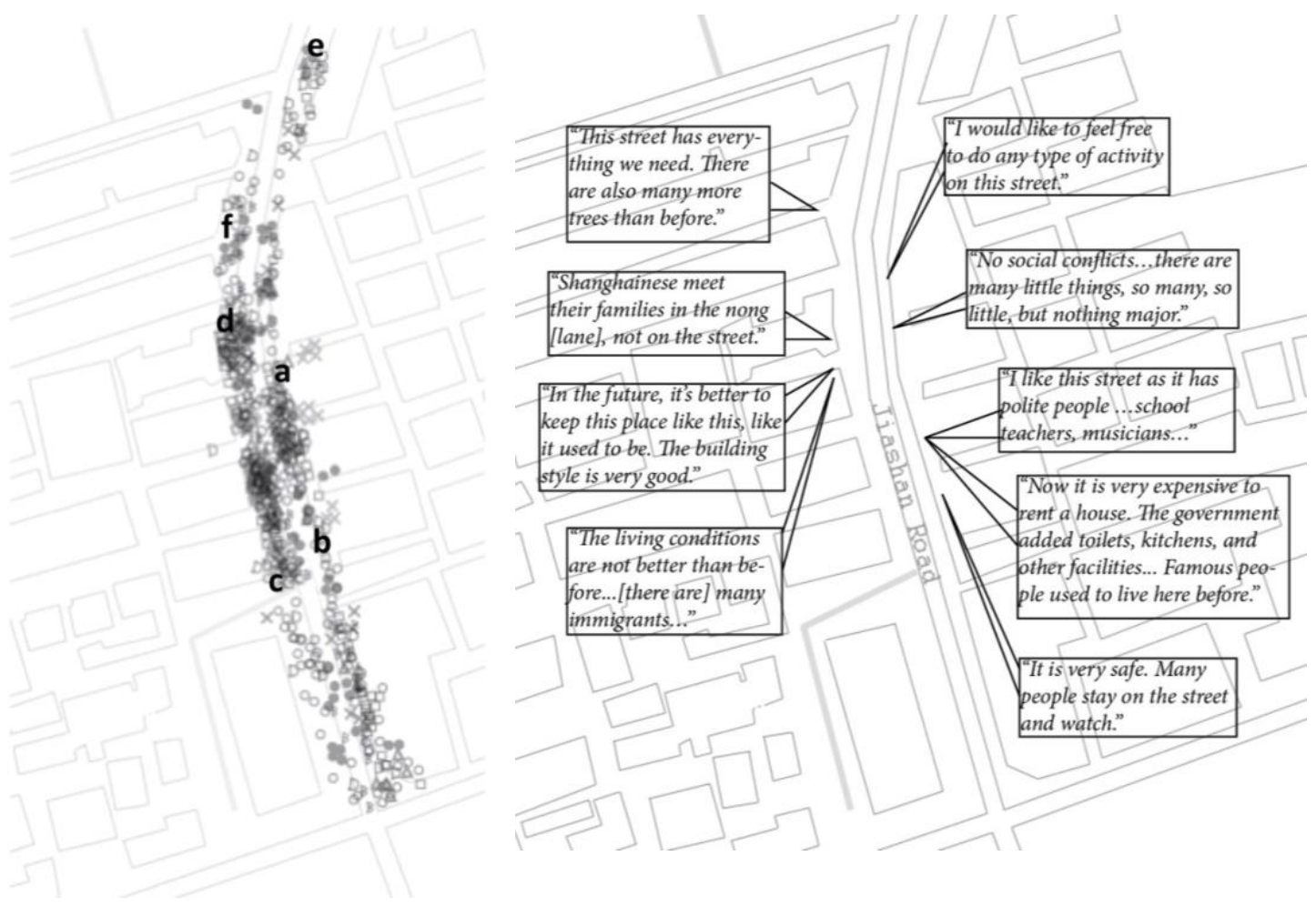

WEEKDAY (at the intervals 9:30am-11:30am; 1:00pm-4:00pm)

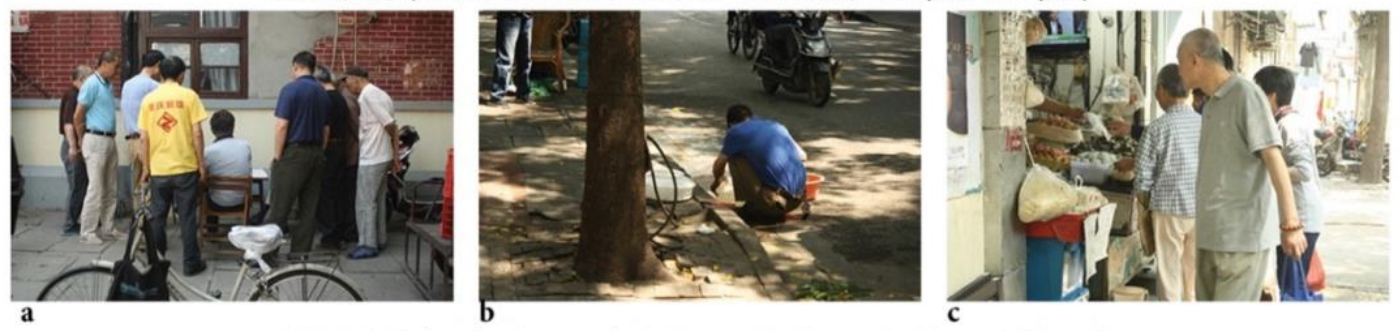

WEEKEND (at the intervals 9:30am-11:30am; 1:00pm-4:00pm)
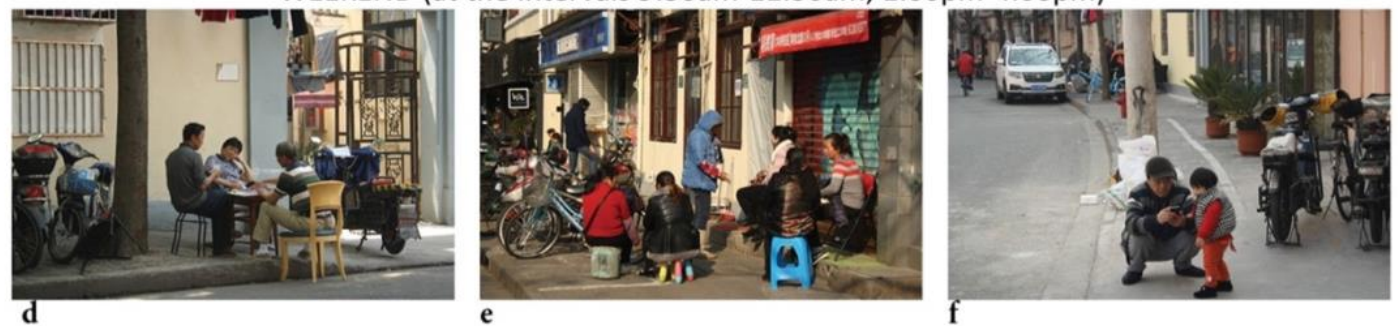


\section{Acknowledgements}

The authors would like to thank all the professionals who participated in this research and to the anonymous reviewers for their valuable comments. The authors declare no conflicts of interest with respect to the research, authorship or publication of this article.

\section{References}

Appleyard, D. (1981) Livable Streets: University of California Press, Berkeley 94720.

Appleyard, B., and Cox, L. (2006) At Home in the Zone', 30-35. Retrieved from https://nacto.org/docs/usdg/at_home_in_the_zone_appleyard.pdf

Appleyard, D., and Lintell, M. (1972) The environmental quality of city streets: The residents' View Point. Journal of the American Institute of Planners. (11-2), 11-2-1 to 11-2-10.

Balsas, C. J. (2004) Measuring the livability of an urban centre: an exploratory study of key performance indicators. Planning Practice and Research, 19(1), 101-110. https://doi.org/10.1080/0269745042000246603

Bosselmann, P., Macdonald, E., and Kronemeyer, T. (1999) Livable Streets Revisited. APA JOURNAL, 168-180.

Carmona, M. (2014). London's local high streets: The problems, potential and complexities of mixed street corridors. Progress in Planning, 100, 1-84. https://doi.org/10.1016/j.progress.2014.03.001

Carmona, M.; Heath, T.; Oc, T.; Tiesdell, S. (2010) Public Places - Urban Spaces. The dimensions of urban design. 2nd ed. Oxford: Architectural Press.

Castillo, H., and Pitfield, D. E. (2010) ELASTIC - A methodological framework for identifying and selecting sustainable transport indicators. Transportation Research Part D: Transport and Environment, 15(4), 179188. https://doi.org/10.1016/j.trd.2009.09.002

Cha, X., Jian, Y., and Li, D. (2014) Humble Opinion on Design of Livable Urban Living Streets [in Chinese]. Residential Science and Technology [收稿日期], 14-17.

Cheng, J., Wang, Z., Zhou, T., Yang, S., Liu, M., and Bian, F. (2007) Design and Traffic Organization for UltraWide Urban Street in China. 3rd Urban Street Symposium, Seattle, Washington.

Clifton, K. J., Livi Smith, A. D., and Rodriguez, D. (2007) The development and testing of an audit for the pedestrian environment. Landscape and Urban Planning, 80(1-2), 95-110. https://doi.org/10.1016/j.landurbplan.2006.06.008 
Deng, B., Wang, H., Chen, J., Wang, X., and Chen, X. (2013) Traffic Accidents in Shanghai - General Statistics and in-Depth Analysis. Retrieved from https://www-esv.nhtsa.dot.gov/Proceedings/23/isv7/main.htm

Du, N., Fu, L., and Fang, G. (2012). Place Making of Vital Street Space in Low-Income Community: Taking Yexie Large Residential Area as an Example [in Chinese]. Urban Planning Journal [城市规划学刊], 205, 149-153.

Dumbaugh, E. (2005) Safe Streets, Livable Streets. Journal of the American Planning Association, 71(3), 283300. https://doi.org/10.1080/01944360508976699

Dumbaugh, E., \& King, M. (2018) Engineering Livable Streets: A Thematic Review of Advancements in Urban Street Design. Journal of Planning Literature, 33(4), 451-465. https://doi.org/10.1177/0885412218783471

Ewing, R., and Cervero, R. (2010) Travel and the built environment: A meta-analysis. Journal of the American Planning Association, 76(3), 265-294. Retrieved from http://dx.doi.org/10.1080/01944361003766766

Ewing, R. H., and Clemente, O. (2013) Measuring urban design: Metrics for livable places. Metropolitan planning + design. Washington, D.C.: Island Press.

Fauzi, A. F., \& Aditianata, A. (2018). Spatial Analysis in Determining Physical Factors of Pedestrian Space Livability, Case Study: Pedestrian Space on Jalan Kemasan, Yogyakarta. IOP Conference Series: Earth and Environmental Science, 123, 012042. https://doi.org/10.1088/1755-1315/123/1/012042

Feng, S., Ge, Y., and Chen, X. (2008) Discussion on the livability of urban streets [in Chinese]. Shanxi Architecture [山西建筑]. (25). Retrieved from http://www.cnki.com.cn/Article/CJFDTOTAL-JZSX200825005.htm

Friedmann, J. (2007) Reflections on Place and Place-making in the Cities of China. International Journal of Urban and Regional Research, 31(2), 257-279. https://doi.org/10.1111/j.1468-2427.2007.00726.x

Gallent, N., and Wong, C. (2009) Introduction: Place shaping, spatial planning and liveability: 01/2009; 80(4):353358. Town Planning Review, 80(4), 353-358.

Gaubatz, P. (2008) New Public Space in Urban China: Fewer Walls, More Malls in Beijing, Shanghai and Xining. China Perspectives. (2008/4), 72-83. Retrieved from http://chinaperspectives.revues.org/4743

Gehl, J. (1987) Life between buildings. New York: Van Nostrand Reinhold.

Greenspan, A. (2017) Moveable feasts: Reflections on Shanghai’s street food. Food, Culture and Society, 21(1), 75-88. https://doi.org/10.1080/15528014.2017.1398472 
Hart, J., and Parkhurst, G. (2011) Driven To Excess: Impacts of Motor Vehicles on the Quality of Life of Residents of Three Streets in Bristol UK, 12-30. $\quad$ Retrieved from http://eprints.uwe.ac.uk/15513/1/WTPP_Hart_ParkhurstJan2011prepub.pdf

Harvey, C., and Aultman-Hall, L. (2016) Measuring Urban Streetscapes for Livability: A Review of Approaches. The Professional Geographer, 68(1), 149-158. https://doi.org/10.1080/00330124.2015.1065546

Hillier, B. (2004) Can streets be made safe? URBAN DESIGN International, 9(1), 31-45. https://doi.org/10.1057/palgrave.udi.9000079

Hillier, B. (2014) Space Syntax as a method and as a theory. In V. Oliviera, P. Pinho, L. M. Batista, T. Patatas, and C. Monteiro (Eds.), Our Common Future in Urban Morphology (International Seminar on Urban Form, ISUF). Porto: FEUP. Retrieved from http://isuf2014.fe.up.pt/Hillier.pdf

Istrate, A. L. (2016) Theoretical Foundations on Liveability at the Level of the Street in Shanghai. in Heng C. K. and Zhang Y. (Eds.), Crossroads - Asian Streets in the Dynamic of Change: Symposium proceedings. CASA. NUS. Singapore. pp. 68-75.

Jacobs, J. (1961) The death and life of great American cities. New York: Vintage Books.

Jacobs, A. B. (1995) Great streets (1st MIT Press pbk. ed). Cambridge, Mass: MIT Press.

Kim, A. M. (2015) Sidewalk city: Remapping public space in Ho Chi Minh City. Chicago, London: The University of Chicago Press.

Lang, W., Chen, T., Chan, E. H. W., Yung, E. H. K., \& Lee, T. C. F. (2019) Understanding livable dense urban form for shaping the landscape of community facilities in Hong Kong using fine-scale measurements. Cities, 84, 34-45. https://doi.org/10.1016/j.cities.2018.07.003

Liu, Y., Dijst, M., and Geertman, S. (2014) Residential segregation and well-being inequality between local and migrant elderly in Shanghai. Habitat International, 42, 175-185. https://doi.org/10.1016/j.habitatint.2013.12.005

Liu, K., and Wang, G. (2013) Progress and Prospect of Livable City Researches in China. Journal of Landscape Research, 5(5), 25-26, 30 .

Llewelyn-Davis (2000) Urban Design Compendium 1. London. Retrieved from https://www.newham.gov.uk/Documents/Environment\%20and\%20planning/UrbanDesignCompendium.pdf

Long, Y., and Liu, L. (2017) How green are the streets? An analysis for central areas of Chinese cities using Tencent Street View. PLOS ONE, 12(2), e0171110. https://doi.org/10.1371/journal.pone.0171110 
Mahmoudi, M., Ahmad, F., and Abbasi, B. (2014) Livable streets: The effects of physical problems on the quality and livability of Kuala Lumpur streets. Elsevier. (43), 104-114. https://doi.org/10.1016/j.cities.2014.11.016

Marshall, W. E., \& McAndrews, C. (2017) Understanding Livable Streets in the Context of the Arterials that Surround Them. Transportation Research Record: Journal of the Transportation Research Board, 2605(1), 1-17. https://doi.org/10.3141/2605-01

Mehta, V. (2007) Lively Streets. Journal of Planning Education and Research, 27(2), 165-187. https://doi.org/10.1177/0739456X07307947

Mehta, V. (2008) Walkable streets: Pedestrian behavior, perceptions and attitudes. Journal of Urbanism, 1(3), 217245. https://doi.org/10.1080/17549170802529480

Mandhar, M., \& Watt, K. (2011) Liveable Streets in the Context of East and West: A New Perspective. Design Principles and Practices: An International Journal, 5. http://eprints.lincoln.ac.uk/7901/1/7901_edited.pdf

McAndrews, C., \& Marshall, W. (2018) Livable Streets, Livable Arterials? Characteristics of Commercial Arterial Roads Associated With Neighborhood Livability. Journal of the American Planning Association, 84(1), 33-44. https://doi.org/10.1080/01944363.2017.1405737

Miao, P. (2011) Brave New City: Three Problems in Chinese Urban Public Space since the 1980s. Journal of Urban Design, 16(2), 179-207. https://doi.org/10.1080/13574809.2011.548980

Montgomery, J. (1998) Making a city: Urbanity, vitality and urban design. Journal of Urban Design, 3(1), $93-116$. https://doi.org/10.1080/13574809808724418

Oranratmanee, R., \& Sachakul, V. (2014) Streets as Public Spaces in Southeast Asia: Case Studies of Thai Pedestrian Streets. Journal of Urban Design, 19(2), 211-229. https://doi.org/10.1080/13574809.2013.870465

Orum, A. M., Bata, S., Li, S., Tang, J., Sang, Y., and Nguyen, T. T. (2009) Public Man and Public Space in Shanghai Today. City and Community, 8:4, 369-389.

Park, Y., \& Garcia, M. (2019) Pedestrian safety perception and urban street settings. International Journal of Sustainable Transportation, 1-12. https://doi.org/10.1080/15568318.2019.1641577

Pacione, M. (2003) Introduction on urban environmental quality and human wellbeing. Landscape and Urban Planning, 65(1-2), 1-3. https://doi.org/10.1016/S0169-2046(02)00231-1

People's Daily. (2015) Conference on Urban Development Lays out Solutions for China's Urban Problems. Retrieved from http://en.people.cn/n/2015/1222/c90000-8994118.html 
Pucher, J., Peng, Z.-r., Mittal, N., Zhu, Y., and Korattyswaroopam, N. (2007) Urban Transport Trends and Policies in China and India: Impacts of Rapid Economic Growth. Transport Reviews, 27(4), 379-410. https://doi.org/10.1080/01441640601089988

Qin, M., Bu, J., and Lin, T. (2003) Livable Streets. Urban Plan, Landscape Architecture and Virescence, 21(04/2003), 74-80.

Riggs, W., \& Gilderbloom, J. (2016). Two-Way Street Conversion. Journal of Planning Education and Research, 36(1), 105-118. https://doi.org/10.1177/0739456X15593147

Sanders, P., Zuidgeest, M., \& Geurs, K. (2015). Liveable streets in Hanoi: A principal component analysis. Habitat International, 49, 547-558. https://doi.org/10.1016/j.habitatint.2015.07.001

Shanghai Street Design Guidelines [in Chinese] (2016) Retrieved from http://up.caup.net/pdf/shanghai-jiedaodaoze.pdf

Sivam, A., and Karuppannan, S. (2013) The role of streets within placemaking in cross - cultural contexts: Case studies from Adelaide, Australia and Georgetown, Malaysia. Retrieved from http://search.ror.unisa.edu.au/media/researcharchive/open/9915910188301831/53108686500001831

Southworth, M. (2016) Learning to make liveable cities. Journal of Urban Design, 21(5), 570-573. https://doi.org/10.1080/13574809.2016.1220152

Stevens, Q. (2009) 'Broken' public spaces in theory and in practice. Town Planning Review (TPR), 80(4-5), 371391. https://doi.org/10.3828/tpr.2009.3

Tang, J., and Long, Y. (2018) Measuring visual quality of street space and its temporal variation: Methodology and its application in the Hutong area in Beijing. Landscape and Urban Planning, 191(October 2018), 103436. https://doi.org/10.1016/j.landurbplan.2018.09.015

Tongji 408 Group - Environmental Design Research (2019) How to make a better street - results of the national questionnaires for the "Street Design Guideline" standard [in Chinese]. available at https://mp.weixin.qq.com/s/WOp-4N3Z8-joDVo4QlyY1A

Van Kamp, I., Leidelmeijer, K., Marsman, G., and de Hollander, A. (2003) Urban environmental quality and human well-being. Towards a conceptual framework and demarcation of concepts; a literature study. Landscape and Urban Planning, 65, 5-18.

Wang, S., Zhu, D., and Zhang, M. (2011) Step out of the Paradox of Livable City Studies: Conceptual Model and Path Choice. China City Planning Review, 20(1), 56-65.

Whyte, W. H. (1980) The social life of small urban spaces. Washington, DC: Conservation Foundation. 
World Bank. (1996) Livable cities for the 21st century. Directions in development. Washington, D.C.: World Bank.

Xie, J. (2012) Human Dimensions of the Street: The Origin and Formation of the Traditional Chinese Street in the Tang-Song Period. Journal of Urban Design, 17(3), 389-412.

Ye, Y., Zeng, W., Shen, Q., Zhang, X., and Lu, Y. (2019) The visual quality of streets: A human-centred continuous measurement based on machine learning algorithms and street view images. Environment and Planning B: Urban Analytics and City Science, 46(8), 1439-1457. https://doi.org/10.1177/2399808319828734

Yu, P. (2012) Masterplanning Chinese New Towns: Designing Permeable Connection and Movement Framework for New Town Development. In A. Williams and T. Dounas (Eds.), Masterplanning the future: Modernism: east, west and across the world. pp. 195-215.

Yuan, R. (2005) Livable City Standards and Development in China. China and World Economy, 13(5), 104-113. 